Prevod obezbedio

autor

\section{RASTUĆA ULOGA} BANAKA U REALIZACIJI PROJEKATA ENERGETSKE EFIKASNOSTI U REPUBLICI SRBIJI

\title{
Rezime
}

Tržište energetske efikasnosti u Republici Srbiji, iako sa velikim potencijalom, još uvek se nalazi u početnim fazama svog razvoja. Predmet ovog rada je analiza nekih aspekata tržišta energetske efikasnosti u Republici Srbiji, sa ciljem rasvetljavanja mogućnosti i ukazivanja na rastuću ulogu banaka u realizaciji ovih projekata. Polazeći od motiva i faktora razvoja tržišta energetske efikasnosti u našoj zemlji, najpre je analiziran regulatorni okvir kao osnov poslovnih mogućnosti koje se pružaju svim potencijalnim i zainteresovanim partnerima za realizaciju ove vrste projekata. Istraživanje se dalje fokusira na moguće uloge i rastući značaj banaka u ovoj perspektivnoj oblasti. Takođe, rad analizira i modalitete finansijske podrške koji su poželjni i prisutni na tržištu energetske efikasnosti kako na domaćem tako i na tržištu Evropske unije kao ilustraciju sistema finansijskih instrumenta koji je razvijen i čije postojanje stimulativno utiče na dalji razvoj faktora tržišta energetske efikasnosti.

Ključne reči: energetska efikasnost, energetski menadžment, banke, finansiranje, javno-privatno partnerstvo, investiranje 


\section{THE GROWING ROLE OF BANKS IN THE IMPLEMENTATION OF ENERGY EFFICIENCY PROJECTS IN THE REPUBLIC OF SERBIA}

Slađana Sredojević

Association of Serbian Banks sladjana.sredojevic@ubs-asb.com
Translation provided by the author

\section{Summary}

Energy efficiency market in the Republic of Serbia, though with great potential, is still in the early stages of its development. The subject of this paper is to analyze some aspects of the energy efficiency market in the Republic of Serbia, with the aim to highlight the opportunities and growing role of banks in the implementation of these projects. Having in mind the motives and factors of energy efficiency market development in our country, the paper starts with an analysis of the regulatory framework as the base of business opportunities that are provided to all potential and interested partners to carry out these types of projects. The study then focuses on the possible role and growing importance of banks in this promising field, as well as on the modalities of financial support which are common for the energy efficiency market both on the domestic market and the European Union market - as an illustration of the framework of financial instruments that has been developed to stimulate and further develop the factors of the energy efficiency market.

Key words: energy efficiency, energy management, banks, financing, Public-Private Partnerships, investments 


\section{Uvod}

Strategijom razvoja energetike Republike Srbije do 2025. godine sa projekcijama do 2030. godine ("Službeni glasnik RS", broj 101/15), energetska efikasnost i veće korišćenje obnovljivih izvora energije svrstani su među prioritete.

Unapređenje energetske efikasnosti kako u sektorima proizvodnje tako i u sektorima potrošnje energije prepoznato je kao jedan od ključnih elemenata energetske politike Republike Srbije, s obzirom da doprinosi sigurnosti snabdevanja energijom, smanjenju potrošnje energije u privatnom $i$ komercijalnom sektoru, povećanju konkurentnosti industrije i povećanju standarda građana. Ne manje značajni su i doprinosi smanjenju uvozne zavisnosti i negativnih posledica sektora energetike na životnu sredinu, a naročito emisije gasova koji stvaraju efekat staklene bašte.

Sprovođenje mera koje su potrebne za postizanje takvog cilja iziskuje više aspekata: mobilizaciju značajnih finansijskih sredstava, proširenje aktivnosti države radi poboljšavanja energetske efikasnosti i dalju liberalizaciju energetskog tržišta, naročito na strani ponude energetskih usluga, kao i razvoj javno-privatnog partnerstva $u$ oblasti energetske efikasnosti. Ovaj rad ima za cilj da rasvetli upravo ove pobrojane odrednice koje karakterišu trenutni stepen razvoja tržišta energetske efikasnosti u Republici Srbiji, sa posebnim akcentom na mogućnosti poslovnih banaka u zemlji za njegovo finansiranje.

\section{Osnovni motivi i faktori razvoja tržišta energetske efikasnosti $u$ Republici Srbiji}

Energetska efikasnost prvenstveno podrazumeva smanjenje potrošnje energije uz istovremeno održanje uslova života i rada, kvaliteta usluga i procesa proizvodnje na nivou koji su najmanje jednaki postojećim. Energetska efikasnost se postiže na dva načina: smanjenjem potrošnje energije ili smanjenjem energetskih gubitaka. Iako se energetska efikasnost, prema tome, može postići spontanim i neorganizovanim delovanjem $\mathrm{u}$ navedenim pravcima, njeno delovanje i krajnji učinci u punom smislu mogu nastati samo kao rezultat postavljenih formalnih politika, organizovanog i sistemskog pristupa i adekvatne uključenosti različitih zainteresovanih strana.

U skladu sa tim i na razvoj tržišta energetske efikasnosti u Republici Srbiji deluje više motiva i faktora koji imaju političko-ekonomsko uporište:

Prvo, međunarodna regulativa u ovoj oblasti je snažan pokretač poslovnih mogućnosti u ovoj oblasti. U 2006. godini u Republici Srbiji je usvojen Zakon o ratifikaciji ugovora o osnivanju Energetske zajednice između Evropske zajednice i Republike Albanije, Republike Bugarske, Bosne i Hercegovine, Republike Hrvatske, BJR Makedonije, Republike Crne Gore, Rumunije, Republike Srbije i privremene misije UN na Kosovu, u skladu sa rezolucijom 1244 Saveta bezbednosti Ujedinjenih nacija (u daljem tekstu "Ugovor o osnivanju Energetske zajednice"). Prema Ugovoru o osnivanju Energetske zajednice, obaveza je države da glavnu legislativu u oblasti energetike, $\mathrm{u}$ velikoj meri, uskladi sa Trećim energetskim paketom EU, naročito u oblastima električne energije, gasa, obnovljivih izvora energije i zaštiti životne sredine. Takođe, u oktobru 2012. godine usvojena je nova Direktiva o energetskoj efikasnosti (2012/27/EU). Acquis energetske efikasnosti zahteva primenu mera za povećanje efikasnosti duž lanca snabdevanja u proizvodnji, prenosu, distribuciji i krajnjoj potrošnji. Mere su uglavnom usmerene na javni sektor i saobraćaj (Bratković et al, 2016)

Drugo, analogno preuzetim obavezama, postoji obaveza transpozicije seta direktiva EU u nacionalno zakonodavstvo a koje se odnose na krajnje potrošače energije, snabdevače energijom, energetske efikasnosti zgrada, označavanja proizvoda koji koriste energiju i sl. Glavne smernice ovih direktiva su već uspostavljene Zakonom o efikasnom korišćenju energije („Službeni glasnik RS”, broj 25/13) i Zakonom o energetici („Službeni glasnik RS", broj 145/14). Na osnovu obaveza Republike Srbije koje proističu iz Ugovora o osnivanju Energetske zajednice, Odluke Ministarskog saveta Energetske zajednice broj 2009/05/MCEnc od 18. decembra 2009. godine kojom je Republika Srbija prihvatila obavezu primene Direktive 2006/32/ EC o energetskoj efikasnosti 


\section{Introduction}

The Energy Strategy of the Republic of Serbia until 2025 with projections to 2030 ("RS Official Gazette" No. 101/2015), classifies energy efficiency and greater use of renewable energy sources among the priorities.

Improving energy efficiency both in production sectors and in energy consumption sectors has been recognized as one of the key elements of the energy policy of the Republic of Serbia, since it contributes to the security of energy supply, reduction of energy consumption in the private and commercial sector, growth of the industry competitiveness and improved standard of living. No less important are contributions to the reduction of import dependence and of adverse consequences of the energy sector on the environment, in particular emissions of greenhouse gases.

The implementation of measures that are necessary to achieve this goal includes a number of aspects: the mobilization of substantial financial resources, expansion of activities of the state to improve energy efficiency and further liberalization of the energy market, particularly on the supply side of energy services, as well as the development of public-private partnerships in the field of energy efficiency. This paper aims to shed light precisely on these listed guidelines that characterize the current level of energy efficiency market development in the Republic of Serbia, with a special emphasis on the possibilities of domestic commercial banks to participate in its financing.

\section{Major motives and factors of energy efficiency market development in Serbia}

Energy efficiency primarily means reducing energy consumption while maintaining the conditions of life and work, service quality and production processes at a level at least equal to the existing one. Energy efficiency is achieved in two ways: by reducing energy consumption and by reducing energy losses. Although energy efficiency can, therefore, be achieved by spontaneous and unorganized operations in these directions, its performance and the ultimate effects in the full sense can only arise as a result of the set of formal policies, organized and systematic approach and proper involvement of various stakeholders.

According to this, the development of the energy efficiency market in Serbia is driven by multiple motives and factors which have a political and economic stronghold:

First, the international regulation in this area is a strong driver of business opportunities in this field. In 2006, the Republic of Serbia adopted the Law on Ratification of the Treaty Establishing the Energy Community between the European Community and the Republic of Albania, Bulgaria, Bosnia and Herzegovina, Republic of Croatia, FYR Macedonia, Montenegro, Romania, Serbia and the UN Interim Administration Mission Kosovo in accordance with the Resolution 1244 of the United Nations (hereinafter referred to as "the Treaty Establishing the Energy Community"). According to the Treaty Establishing the Energy Community, it is the obligation of the state to harmonize the domestic legislation in the field of energy with the Third Energy Package of the EU, particularly in the areas of electricity, gas, renewable energy, and environmental protection. Also, in October 2012 a new Directive on Energy Efficiency (2012/27 / EU) has been adopted. In the energy efficiency field acquis requires the implementation of measures to increase efficiency along the supply chain in the production, transmission, distribution and final consumption. Measures are mainly aimed at the public sector, transportation (Bratković et al, 2016).

Secondly, in line with the undertaken obligations, there is an obligation of transposing into the national legislation the set of EU directives related to the final consumers of energy, energy suppliers, energy efficiency in buildings, labeling of energy-using products, etc. The main guidelines of these directives have already been established by the Law on Efficient Use of Energy ("Official Gazette of RS", No. 25/13) and the Law on Energy ("Official Gazette of RS, No. 145/14). Based on the obligations of the Republic of Serbia arising from the Treaty Establishing the Energy Community, the Decision of the Ministerial Council of the Energy Community No 2009/05/MC-Enc of 18 December 2009, by which the Republic of Serbia 
u sektorima potrošnje energije, kao i Zakona o efikasnom korišćenju energije, donet je Zaključak o usvajanju Drugog akcionog plana za energetsku efikasnost Republike Srbije za period od 2013. do 2015. godine (Ministarstvo rudarstva i energetike, 2013). Drugi Akcioni plan je strateški dokument kojim se u oblasti unapređenja energetske efikasnosti u Republici Srbiji zadaju specifični kvantitativni ciljevi energetskih ušteda u skladu sa opštim ciljevima drugih strateških dokumenata iz ove oblasti. Nakon prvog Nacionalnog akcionog plana za energetsku efikasnost iz 2010. godine, drugim Akcionim planom predviđa se niz mera za unapređenje energetske efikasnosti u sektorima domaćinstva, javnog i komercijalnog sektora, industrije i saobraćaja. Srednji indikativni cilj Akcionog plana utvrđen je na nivou od 3,5\% domaće potrošnje finalne energije u 2008. godini (0,2952 Mtoe). Tokom 2016 godine očekuje se donošenje "Trećeg akcionog plana za energetsku efikasnost Republike Srbije".

Inače, $u$ proteklom periodu usvojen je i niz podzakonskih akata kojima se omogućava dalja primena Zakona o energetici i Zakona o efikasnom korišćenju energije.

Treće, uvođenje niza novih mehanizama učinjeno je po ugledu na najbolju praksu u ovoj oblasti, kao što je, između ostalog, sistem energetskog menadžmenta. Novi mehanizmi i poslovni procesi podsticajno deluju na afirmaciju energetske efikasnosti, posredno i neposredno.

Četvrto, energetska efikasnost (EE) i obnovljivi izvori energije (OIE) su oblasti koje se graniče sa drugim segmentima koje na sličan način predstavljaju potencijal rasta ali i poslovnu mogućnost. Potrebe za finansiranjem istih, kao i mogućnost uvođenja novih finansijskih instrumenata, proizvoda i tehnika su već prisutne i na našem tržištu sa tendencijom njihovog rasta u budućnosti. U ovoj sferi, važno je pomenuti postojanje mogućnosti Zakona o javno-privatnom partnerstvu i koncesijama ("Službeni glasnik Republike Srbije" br. 88/2011, 15/2016), kao i Zakona o ulaganjima ("Službeni glasnik Republike Srbije" br. 89/2015) koji javnom sektoru daju mogućnost realizacije projekata od javnog značaja (kapitalnih investicija) angažovanjem sredstava, tehnologije, knowhow i drugih kapaciteta privatnog sektora domaćeg ili stranog porekla.

Imajući u vidu gore navedeno, zaključuje se da je zakonodavni okvir u Republici Srbiji kompleksan, kompatibilan sa međunarodnom praksom i preuzetim obavezama i da predstavlja dobar osnov za realizaciju poslovnih mogućnosti u ovoj oblasti. Potencijal za finansiranje ovih projekata je ogroman i banke imaju mogućnost da se blagovremeno pozicioniraju u skladu sa ovim predstojećim i rastućim potrebama različitih javnih tela (javnog sektora). Rad se u svom nastavku dalje bavi analizom mogućnosti koje donosi oblast energetske efikasnosti i sistem energetskog menadžmenta, ali i analizom trenutnih izazova koji postoje u fazi investiranja u ove projekte. Posebno će biti istaknuti instituti i mehanizmi koji su u regulativi uspostavljeni, a koji vrlo pogoduju kako opštoj predvidivosti i stabilnosti poslovnog dugoročnog aranžmana, kakvi su

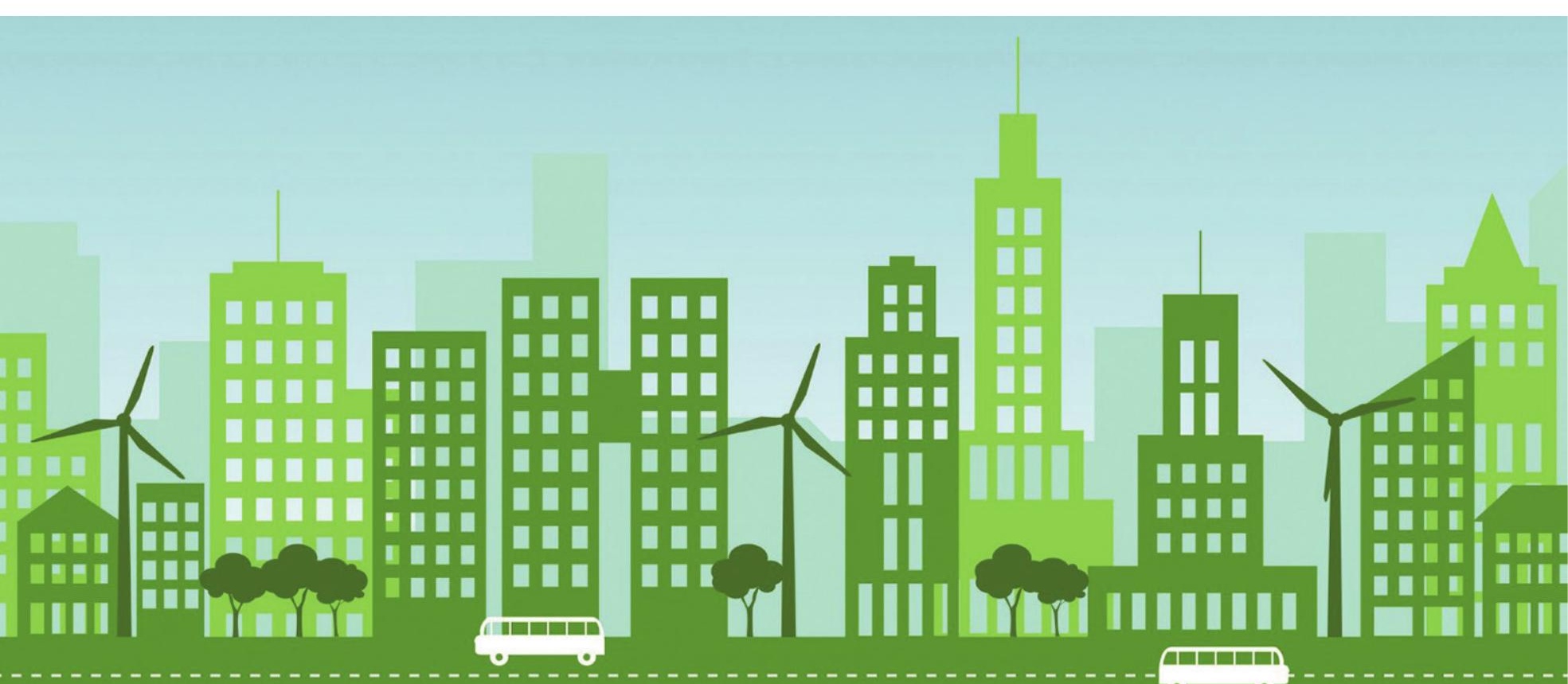


accepted the obligation to apply the Directive 2006/32/EC on energy efficiency in the sectors of energy consumption, as well as the Law on the Efficient Use of Energy, the Resolution on the adoption of the Second action plan for energy efficiency of the Republic of Serbia for the period from 2013 to 2015 has been issued (Ministry of Mining and Energy, 2013). The second action plan is a strategic document in the field of improving energy efficiency in the Republic of Serbia by setting specific quantitative targets for energy savings in line with the overall objectives of other strategic documents in this field. After the first National Action Plan for Energy Efficiency in 2010, the second Action Plan envisages a series of measures to improve energy efficiency in households, public and commercial sector, industry and transport. Central indicative target of the Action Plan was established at the level of $3.5 \%$ of domestic consumption of final energy consumption in 2008 (0,2952 Mtoe). In the course of 2016 the adoption of the "Third Action Plan for Energy Efficiency of the Republic of Serbia" is expected.

In the recent period, a series of by-laws has been adopted with an aim to further implement the Energy Law and the Law on Efficient Use of Energy.

Thirdly, a series of new mechanisms have been introduced on the basis of the best practice in this field, such as, inter alia, the energy management system. New mechanisms and business processes have a stimulating effect on the recognition of energy efficiency, both directly and indirectly.

Fourthly, energy efficiency (EE) and renewable energy sources (RES) are the areas bordering on other segments which likewise represent both a growth potential and a business opportunity. The financing needs are the same, and the possibility of introducing new financial instruments, products and techniques are already present in our market with the tendency of their growth in the future. In this sphere, it is important to mention the existence of the possibility of the PublicPrivate Partnership and Concessions ("Official Gazette of the Republic of Serbia" No.88/2011, 15/2016) and the Law on Investments ("Official Gazette of the Republic of Serbia" No.89/2015) which gives the public sector the possibility of implementing projects of public interest (capital investment) engaging resources, technology, know-how and capacities of the private sector, of domestic or foreign origin.

Bearing in mind all of the above, it is evident that the legislative framework in Serbia is complex, compatible with international practice and commitments and that it represents a good basis for the realization of business opportunities in this field. The potential for funding of these projects is huge and banks have the ability for timely positioning in accordance with these upcoming and growing needs of the various public bodies (public sector). The paper will further analyze the opportunities provided by the area of energy efficiency and energy management system, as well as the current challenges that exist in the investment stage in these projects. The special highlight will be placed on prominent institutes and mechanisms that have been established in the regulation which are very favorable for both the general predictability and stability of long-term business arrangements such as EE projects, and particularly for the position and the interests of banks, potential investors and financiers.

\section{Implementation of the energy management system}

Law on Efficient Use of Energy was adopted in March 2013 and it introduced a new term - energy management system, which in the narrow sense of the word means organized energy management. Based on the Decree on establishing limits power consumption on the basis of which it is determined which companies are liable to the energy management system, the annual objectives of energy savings and the application form on the realized energy consumption, large energy consumers have a legal obligation to save energy, such as economic society (i.e. ratepayer) if at least one location, which is kept at a separate address, have facilities for carrying out activities which generated the annual consumption of primary energy greater than the limit value of energy consumption prescribed by the Government regulations (Ministry of Mining and Energy, 2016). Thus, for example, companies are liable if the system on at least one location, which 
projekti u EE, tako i posebno položaju i interesu banaka, potencijalnih investitora i finansijera.

\section{Uvođenje sistema energetskog menadžmenta}

Zakon o efikasnom korišćenju energije donet je u martu 2013. godine i uvodi novi pojam - sistem energetskog menadžmenta, što $u$ užem smislu reči znači organizovano upravljanje energijom. Na osnovu Uredbe o utvrđivanju graničnih vrednosti godišnje potrošnje energije na osnovu kojih se određuje koja privredna društva su obveznici sistema energetskog menadžmenta, godišnjih ciljeva uštede energije i obrasca prijave o ostvarenoj potrošnji energije, veliki potrošači energije imaju zakonske obaveze da štede energiju, kao što su privredna društva ( $\mathrm{zv}$. Obveznici sistema) ukoliko na najmanje jednoj lokaciji, koja se vodi na posebnoj adresi, imaju objekte za obavljanje delatnosti čija je ostvarena godišnja potrošnja primarne energije veća od graničnih vrednosti potrošnje energije koji uredbom propiše vlada (Ministarstvo rudarstva i energetike, 2016). Tako, npr. privredna društva su obveznici sistema ukoliko na najmanje jednoj lokaciji, koja se vodi na posebnoj adresi, imaju objekte za obavljanje delatnosti čija je ostvarena godišnja potrošnja primarne energije veća od sledećih graničnih vrednosti potrošnje energije:1) 2.500 toe - tona ekvivalentne nafte (104,67 TJ ili 29,08 GWh) godišnje za privredna društva čija je pretežna delatnost $\mathrm{u}$ proizvodnom sektoru; 2) 1.000 toe - tona ekvivalentne nafte $(41,87 \mathrm{TJ}$ ili 11,63 GWh) godišnje za privredna društva čija je pretežna delatnost u sektoru trgovine i usluga.

Godišnji cilj uštede energije za organe državne uprave, druge organe Republike Srbije i organe autonomne pokrajine kao Obveznike sistema u objektima za koje ti organi plaćaju troškove energije za tekuću kalendarsku godinu iznosi $1 \%$ od potrošnje primarne energije ostvarene u prethodnoj kalendarskoj godini. Godišnji cilj uštede energije za jedinice lokalne samouprave sa više od 20.000 stanovnika kao Obveznike sistema u objektima za koje jedinica lokalne samouprave plaća troškove energije, kao i za ustanove koje obavljaju delatnosti u oblasti obrazovanja, nauke, kulture, zdravstvene zaštite, za tekuću kalendarsku godinu iznosi $1 \%$ od ostvarene potrošnje primarne energije $\mathrm{u}$ prethodnoj kalendarskoj godini. Jedinice lokalne samouprave su obveznici ako imaju zgrade koje prelaze $1.000 \mathrm{~m}^{2}$, kao i organi i javne službe i javna preduzeća. Dakle, glavna obaveza je da dostignu uštede energije, a ukoliko Obveznik sistema u jednoj kalendarskoj godini ostvari uštedu energije veću od one koja je propisana ovom uredbom, ona mu se srazmerno obračunava kao ušteda u narednih pet godina.

Energetski menadžment podrazumeva obavezu imenovanja i novih zvanja energetskih menadžera, a to su fizička lica koja prolaze obuku, dobijaju licencu koju izdaje Ministarstvo, i rade analizu podataka o korišćenju energije, pripremaju planove energetske efikasnosti, prave planove uštede i dostavljaju izveštaje ministarstvu. Ministarstvo je izradilo Pravilnik o uslovima u pogledu kadrova, opreme i prostora organizacije koja sprovodi obuku za energetske menadžere i ovlašćene energetske savetnike („Službeni glasnik RS", broj 12/15), raspisalo javni poziv, i donelo odluku da Mašinski fakultet Univerziteta u Beogradu bude institucija koja će obavljati obuke energetskih menadžera, za oblast opštinske, industrijske energetike i energetike zgrada.

Ovlašćeni energetski savetnik je takođe novo zvanje, a to može biti fizičko i pravno lice koje najpre mora polagati obuku za energetskog menadžera, dok obuku sprovodi Mašinski fakultet. Savetnici će, između ostalog, raditi energetske preglede, i o tome će se voditi evidencija u Ministarstvu. Ceo sistem je razvijen u okviru projekta JICA podržanom od Vlade Japana i Japanske agencije za međunarodnu saradnju koji omogućavaju sprovođenje ovog celog sistema energetskog menadžmenta.

\section{Rastuća uloga banaka u oblasti energetske efikasnosti}

\section{Banke kao partneri na nivou projekta - multisektorska ekspertiza}

Najčešći tipovi projekata u oblasti EE koje banke finansiraju i koje imaju perspektivu u budućnosti su:

- zamena uličnog osvetljenja, 
is kept on a separate address, has facilities for carrying out activities which generated the annual consumption of primary energy higher than the following threshold values of energy consumption: 1) 2,500 toe - tons of oil equivalent (104.67 TJ or 29,08 GWh) per year for companies whose predominant activity is in the manufacturing sector; 2) 1,000 toe - tons of oil equivalent (41.87 or $11.63 \mathrm{TJ}$ GWh) per year for companies whose predominant activity is in the sector of trade and services.

Annual energy savings target for government authorities, other bodies of the Republic of Serbia and the authorities of the autonomous regions as ratepayers in buildings for which these bodies pay the cost of energy for the current calendar year is $1 \%$ of the primary energy consumption recorded in the previous calendar year. Annual energy savings target for local governments with more than 20,000 inhabitants as ratepayers in the facilities for which local governments pay the costs of energy, as well as institutions that perform activities in the field of education, science, culture, healthcare, for the current calendar year is $1 \%$ of the primary energy consumption recorded in the previous calendar year. Local governments are liable if they have a building exceeding $1,000 \mathrm{~m}^{2}$, as well as the authorities and public services and public companies. Thus, the main obligation is to achieve energy savings, and if the ratepayer in a single calendar year achieves energy savings greater than that prescribed by this regulation, it will be proportionately accounted as cost savings over the next five years.

Energy management also includes the responsibility for the appointment of new positions - energy managers, and these are individuals who are trained, and licensed by the Ministry; they are in charge of the analysis of energy usage data, of the preparation of the plans for energy efficiency, the real savings plans and reporting to the Ministry. The Ministry drafted the Ordinance on the conditions in terms of personnel, equipment and facilities of the organization that conducts training for energy managers and authorized energy advisors ("Official Gazette of RS", No. 12/15), issued a public appeal, and decided that the Faculty of Mechanical Engineering, University of Belgrade will be the institution to perform the training of energy managers, in the field of municipal energy, industrial energy and energy of buildings.

The authorized energy adviser is also a new position, and it may be a natural or legal person who must first undertake the training for energy managers, conducted by the Faculty of Mechanical Engineering. Advisers will, among other things, be in charge of energy audits, and the evidence will be kept in the Ministry.

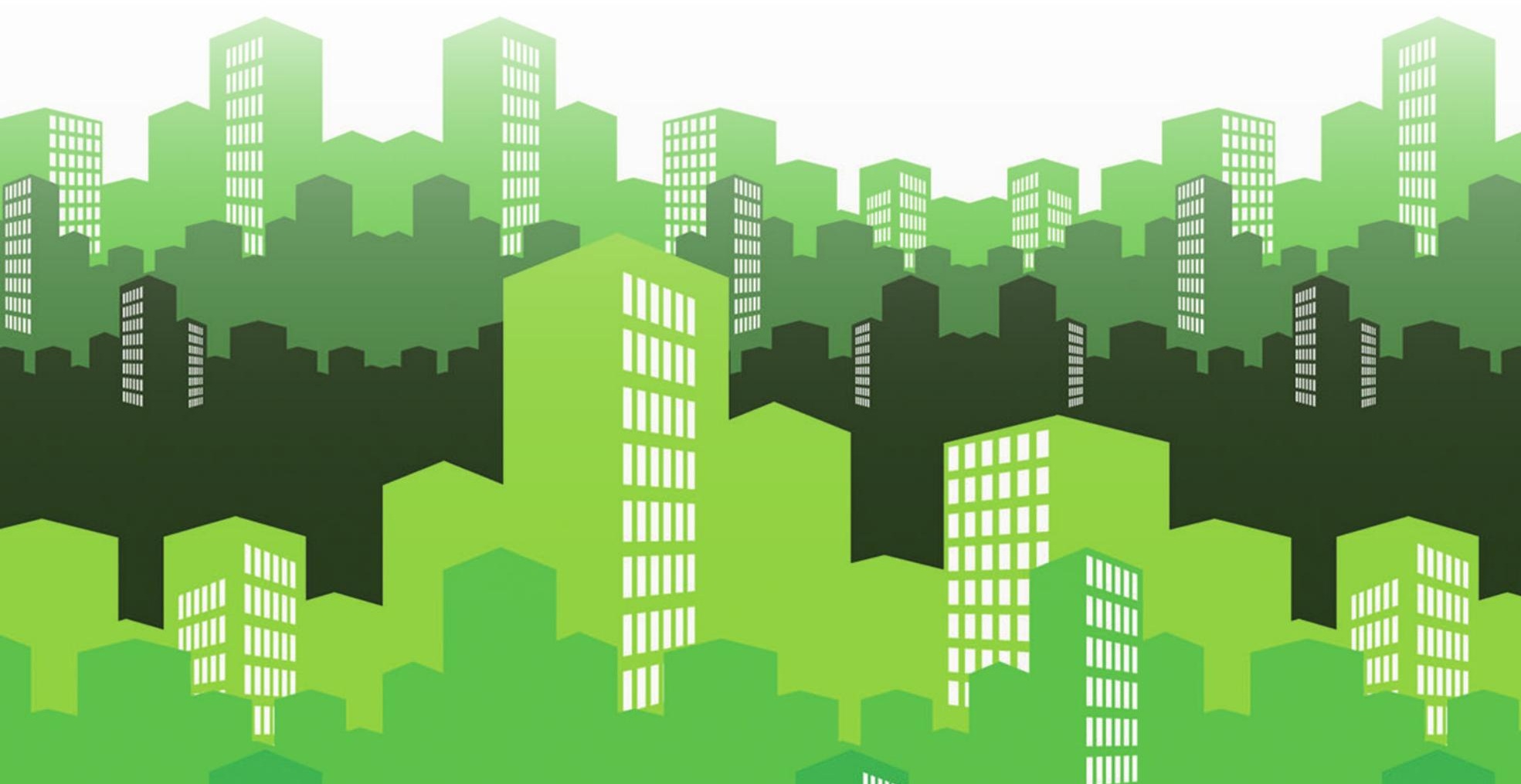


- postavljanje termoizolacije i zamena prozora i vrata,

- poboljšanje sistema grejanja i klimatizacije,

- zamena voznog parka,

- zamena proizvodnih mašina i opreme, poljoprivredne opreme i mašina,

- razna nova, inovativna rešenja.

Kao klijenti banaka i predlagači ovih projekata, javljaju se i fizička lica (stanovništvo) i pravna lica (privreda), kao i sve više rastući broj tzv. ESCO kompanija (videti više u nastavku teksta dole). Iako je broj banaka na tržištu u Srbiji sa značajnijim iskustvom $u$ finansiranju projekata EE relativno mali, banke su važni partneri kako u cilju obezbeđivanja sredstava (finansiranje) tako i u smislu obezbeđivanja ekspertize za projekte različitih sektora. Imajući $\mathrm{u}$ vidu da je oblast EE veoma perspektivna, za očekivati je da se ekspertiza na nivou pojedinačne banke vremenom širi i jača, i da se edukacija u ovoj oblasti odvija kontinuirano kako kod banaka koje već finansiraju ove projekte, tako i kod banaka koje se tek spremaju da uspostave ove poslovne linije.

\section{Banke kao partneri u realizaciji mera ušteda na nacionalnom nivou}

Predviđena uloga banaka podrazumeva, ne samo potencijal banaka za finansiranje povoljnim kreditnim linijama, nego i potencijal banaka kao ravnopravnog partnera u realizaciji nacionalnog cilja uštede energije. Kao sastavni deo Drugog akcionog plana za energetsku efikasnost Republike Srbije za period od 2013. do 2015. godine, prikazane su sve mere uštede koje će biti sprovedene kroz implementaciju ovog plana, sa naznakom na koju staru se odnosi nova mera, dodelom odgovornosti za njihovu implementaciju i pretpostavljenim izvorima finansiranja. Podatak da je od 24 mere (u javnom i komercijalnom sektoru, u sektoru industrije i sektoru transporta, horizontalne mere), kod šest predviđeno direktno učešće banaka kroz povoljne kreditne linije kao potencijalni izvor finansiranja, ilustruje dovoljno važnost i rastuću ulogu banaka u ovim poslovima:

1. Mere unapređenja energetske efikasnosti u stambenim zgradama

2. Mere unapređenja energetske efikasnosti u javnim i komercijalnim zgradama

3. Nova pravila za projektovanje i izgradnju zgrada, minimalni zahtevi u pogledu energetskih svojstava zgrada i njihova sertifikacija u skladu sa revidiranom EPBD.

4. Modernizacija sistema javnog osvetljenja u gradovima i opštinama

5. Uvođenje sistema energetskog menadžmenta kod velikih potrošača energije iz sektora industrije

6. Program unapređenja energetske efikasnosti u sektoru industrije.

\section{Modeli ugovora o energetskoj usluzi}

Premda domaće tržište efikasnog korišćenja energije nije dovoljno razvijeno $u$ ovom trenutku, ono ima veliki potencijal rasta $\mathrm{u}$ budućnosti pošto je usvojen potreban zakonski okvir. Takođe, postoje i novine i mehanizmi regulative koji pogoduju daljoj afirmaciji banaka u oblasti energetske efikasnosti. Među najvažnijim podzakonskim aktima, ističe se Pravilnik o utvrđivanju modela ugovora o energetskim uslugama za primenu mera poboljšanja energetske efikasnosti kada su korisnici iz javnog sektora, usvojen u maju 2015. godine (Ministarstvo rudarstva i energetike, 2015c). Ovaj Pravilnik uređen je kao okvir tako da i drugi potencijalni investitori i finansijeri imaju položaj partnera i definiše dva modela ugovora:

1. Model ugovora o energetskoj usluzi za primenu mera poboljšanja energetske efikasnosti javnih objekata i uštedama u operativnim troškovima tih objekata

2. Model ugovora o energetskoj usluzi za primenu mera poboljšanja energetske efikasnosti i uštedama u operativnim troškovima javnog osvetljenja.

Ovim ugovorima se dozvoljava uspostavljanje javno-privatnog partnerstva između javnog tela sa jedne strane (lokalna samouprava, AP, država) i privatnog partnera sa druge strane koji je odabran putem tendera. U zavisnosti od veličine i složenosti projekta, banka primenjuje tradicionalno kreditiranje, projektno i korporativno finansiranje, kao i raznovrsne inovativne finansijske proizvode (Wiser and Pickle, 1997, p. xiii).

\section{Mogućnost javno-privatnog partnerstva u oblasti energetske efikasnosti}

Veliki broj projekata energetske efikasnosti 
The whole system is developed under the JICA project supported by the Government of Japan and the Japan International Cooperation Agency, which supported the implementation of the entire system of energy management.

\section{Growing role of banks in the energy efficiency field}

\section{Banks as partners on the project level - multi-sector expertise}

The most common types of projects in the field of EE that are financed by the banks and which have great potential in the future are:

- Replacement of street lighting,

- Installation of thermal insulation and replacement of windows and doors,

- Improvements in the heating and air conditioning,

- Replacement of vehicles,

- Replacement of production machinery and equipment, agricultural machinery and equipment,

- Variety of new, innovative solutions.

As clients of banks and the promoters of these projects, there are also individuals (citizens) and legal entities (economy), as well as the ever-growing number of the so-called ESCO companies (see more below). Although the number of banks on the Serbian market with significant experience in financing EE projects is relatively small, the banks are important partners in fund raising, financing and in terms of providing expertise for projects in different sectors. Bearing in mind that the field of electricity is very promising, it is expected that the expertise at the level of individual banks will increase over time and become stronger and that the training in this field will be taking place continuously both in case of banks that are already funding these projects, and in case of banks only getting ready to set up this business line.

\section{Banks as partners in the realization of savings targets at the national level}

The position of banks includes not only the potential of banks to finance via credit lines, but also the potential of banks as equal partners in the realization of the national energy savings target. The Second Action Plan for Energy
Efficiency of the Republic of Serbia for the period from 2013 to 2015 includes the savings measures that will be implemented through the implementation of this plan, indicating which old measure is related to a new one, the allocation of responsibilities for their implementation and assumed sources of funding. The fact that out of 24 measures (in the public and commercial sectors, the industrial sector and the transport sector, horizontal measures) six measures are planned to be provided by direct participation of banks through favorable credit lines as a potential source of funding, is enough to illustrate the importance and the growing role of banks in the following matters:

1. Measures to improve energy efficiency in residential buildings

2. Measures to improve energy efficiency in public and commercial buildings

3. The new rules for the design and construction of buildings, the minimum requirements regarding the energy performance of buildings and their certification in accordance with the revised EPBD

4. Modernization of public lighting in towns and municipalities

5. The introduction of energy management systems for large energy consumers from industry

6. The program to improve energy efficiency in the industry sector.

\section{Models of energy service contracts}

Although the domestic energy efficiency market is not sufficiently developed at this stage, it has great potential for future growth since the required legal framework is in place. There are also innovations and mechanisms of regulation conducive to further promotion of banks in the field of energy efficiency. Among the most important by-laws, there is the adopted Ordinance on establishing model contracts for energy services for the implementation of measures to improve energy efficiency when the users are from the public sector, adopted in May 2015 (Ministry of Mining and Energy, 2015c). This Ordinance is arranged as a framework so that other potential investors and financiers have the status of partners and it defines two models of contracts:

1. Model of the energy service contracts for 
može se realizovati putem javno-privatnog partnerstva, što je posebno velika mogućnost koja je na raspolaganju javnom sektoru kao predlagaču (Sredojević, 2010). Sa druge strane, domaća regulativa, prvenstveno Zakon o javno-privatnom partnerstvu i koncesijama, prepoznaje oblast energetske efikasnosti kao oblast $\mathrm{u}$ kojoj postoji potreba za finansiranjem projekata i to ne samo u načelu, nego i u praksi. Naime, od 36 predloga projekata koji su od Komisije za javno-privatno partnerstvo dobili saglasnost da se mogu sprovoditi modelom javno-privatnog partnerstva (od 2012 do danas), čak 10 predloga projekata odnosi se na oblast energetske efikasnosti na nivou lokalne samouprave:

1. Predlog projekta javno-privatnog partnerstva podnet od strane grada Niša kojim se predlaže zamena kotlova na lož ulje i na ugalj, kotlovima na drvenu biomasu (pelet) u školskim i predškolskim ustanovama grada Niša sa isporukom toplotne energije;

2. Predlog projekta javno-privatnog partnerstva kojim se predlaže obavljanje komunalne delatnosti rekonstrukcije, racionalizacije i održavanja javnog osvetljenja na području opštine Topola;

3. Predlog projekta javno-privatnog partnerstva kojim se predlaže zamena postojećih svetiljki javne rasvete štedljivim "LED" svetiljkama u zoni ulica, parkova, šetališta, na javnim površinama, spoljašnje dekorativne rasvete javnih zgrada i spomenika u naseljima opštine Sečanj;

4. Predlog projekta javnoprivatnog partnerstva kojim se predlaže rekonstrukcija dela sistemajavnog osvetljenja na teritoriji opštine Vrbas.

5. Predlog projekta javnoprivatnog partnerstva kojim se predlaže zamena postojećih kotlova na lož ulje kotlovima na biomasu i ugovorno isporučivanje toplotne energije u objektima Mlekarske škole „Dr Obren Pajić“, OŠ „,Sveti Sava“, OŠ „,Dušan Radović“ i OŠ „,8. septembar" u opštini Pirot;
6. Predlog projekta javno-privatnog partnerstva za rekonstrukciju dela sistema javnog osvetljenja na teritoriji grada Vranja;

7. Predlog projekta javno-privatnog partnerstva za rekonstrukciju dela sistema javnog osvetljenja na teritoriji opštine Varvarin;

8. Predlog projekta javno-privatnog partnerstva za rekonstrukciju, racionalizaciju i održavanje javnog osvetljenja u naseljima opštine Žabalj

9. Predlog projekta javno-privatnog partnerstva za modernizaciju, racionalizaciju i održavanje javnog osvetljenja u naseljima opštine Ada;

10. Predlog projekta javno-privatnog partnerstva za modernizaciju, racionalizaciju i održavanje javnog osvetljenja u naseljima opštine Beočin.

Većina projekata se odnosi na modernizaciju, racionalizaciju i održavanje javnog osvetljenja u gradovima ili opštinama. Jedan od oblika javno-privatnog partnerstva može biti i ESCO kompanija, o čemu svedoče i dva predloga projekta koja su do sada odobrena za dalju realizaciju putem modela javno-privatnog partnerstva $u$ dva grada $u$ Srbiji. ESCO kompanija (eng. Energy Service Company) je kompanija koja upravlja merama poboljšanja energetske efikasnosti na način da su one finansirane iz ostvarenih ušteda koje su garantovane i da ne generišu novi dug na strani javnog tela.

\section{Slika 1. Šematski prikaz saradnje i finansiranja u okviru ESCO koncepta}

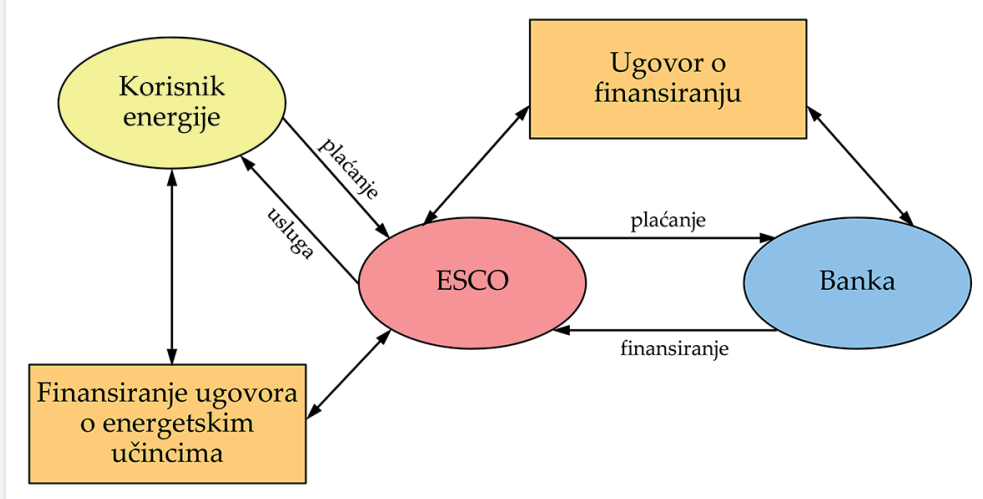

Izvor: autor
Osnovna prednost ovog modela je što je privatni partner taj koji preuzima rizik 
the implementation of measures to improve energy efficiency in public buildings and achieve savings in operating costs of these facilities;

2. Model of the energy service contracts for the implementation of measures to improve energy efficiency and achieve savings in operating costs of public lighting.

These contracts allow the establishment of public-private partnerships between public bodies on the one hand (local self-government, $\mathrm{AP}$, the state) and the private partner on the other hand who is selected through a tender process. Depending on the size and complexity of the project, the bank applies traditional lending, project and corporate financing as well as a variety of innovative financial products (Wiser and Pickle, 1997, p.xiii).

\section{Opportunities for Public-Private Partnerships in the energy efficiency field}

A large number of energy efficiency projects can be implemented through public-private partnership, which is a particularly good possibility for the public sector as the proponent (Sredojević, 2010). On the other hand, domestic legislation, especially the Law on Public-Private Partnership and Concessions, identified the area of energy efficiency as an area which requires funding of projects, not only in principle but also in practice. The 36 project proposals from the Commission for Public-Private Partnership have been given the consent to be implemented by a model of public-private partnership (since 2012 until today), 10 of which are related to the area of energy efficiency at the local level:

1. the proposal of a public-private partnership has been submitted by the city of Niš, which proposes the replacement of boilers fuelled by oil and coal, with the wood biomass (pellet) boilers in schools and preschools city of Niš with the delivery of thermal energy;

2. the project proposal of a public-private partnership that proposes conducting public utilities reconstruction, rationalization and maintenance of public lighting in the municipality of Topola;

3. the proposal of a public-private partnership which proposes replacing the existing public lighting with the energy saving LED lamps in the streets, parks, promenades, public areas, external decorative lighting of public buildings and monuments in the municipality of Sečanj;

4. the proposal of a public-private partnership that proposes a reconstruction of the part of the system of public lighting in the municipality of Vrbas;

5. the proposal of a public-private partnership which proposes replacing the existing boilers fuelled by oil with the biomass boilers and contractual delivery of thermal energy to the Dairy School "Dr Obren Pajić," Elementary School "Sveti Sava", Elementary School "Dušan Radović" and Elementary School " $8^{\text {th }}$ September "in the municipality of Pirot;

6. the proposal of a public-private partnership for the reconstruction of the part of the public lighting in the city of Vranje;

7. the proposal of a public-private partnership for the reconstruction of the part of the public lighting in the municipality of Varvarin;

8. the project proposal of a public-private partnership for the reconstruction, rationalization and maintenance of public lighting in the municipality of Žabalj;

9. the proposal of a public-private partnership for the modernization, rationalization and maintenance of public lighting in the municipality of Ada;

10. the proposal of a public-private partnership for the modernization, rationalization and maintenance of public lighting in the municipality of Beočin.

Most of the projects are related to the modernization, rationalization and maintenance of public lighting in cities or municipalities. One of the forms of public-private partnerships can be ESCOs, as evidenced by the two project proposals which have so far been approved for further implementation by the public-private partnership in two cities in Serbia. ESCOs (i.e. Energy Service Companies) are companies that manage the measures of improvement energy efficiency in such a way that they are financed from savings that are guaranteed and that do not generate new debt on the side of the public bodies. 
ostvarivanja projektovanih i željenih ušteda energije, garantuje povratak uloženih investicionih sredstava iz ostvarenih ušteda i strana koja obezbeđuje finansiranje. Uloga banaka kod javno-privatnog partnerstva i kod ESCO modela je vrlo velika i značajna: ESCO kompanije su partneri banaka u cilju delimičnog ili potpunog obezbeđenja finansiranja projekta. U domaćim okvirima, dalji razvoj ESCO kompanija i tržišta ima vrlo jasnu i svetlu perspektivu.

\section{Domen javnih nabavki}

Ministarstvo rudarstva i energetike usvojilo je Pravilnik o minimalnim kriterijumima $u$ pogledu energetske efikasnosti u postupku javne nabavke dobara (Ministarstvo rudarstva i energetike, 2015b) kojim se propisuju minimalni kriterijumi u pogledu energetske efikasnosti koje naručioci (u smislu zakona kojim se uređuju javne nabavke) određuju u postupku javne nabavke dobara. Iako ovi kriterijumi ne utiču direktno na veći broj projekata energetske efikasnosti koji bi banke finansirale, oni svakako imaju posredan efekat i podstiču podizanje nivoa kvaliteta poslovanja javnih tela koja na ovaj način postaju bolje informisani i upućeni budući klijenti banke koji razumeju značaj i neophodnost poštovanja oblasti energetske efikasnosti.

\section{Specifični sistemi podrške kod finansiranja projekata energetske efikasnosti}

Investiranje $\mathrm{u}$ projekte energetske efikasnosti ima brojne prepreke, kao što su vrlo visoki početni troškovi, transakcioni troškovi, nedostatak kapaciteta, nizak nivo svesti ili razumevanja koncepta finansiranja, ili strukturni problem kao što su tzv. Principalagencijski problemi (ICC, 2014).

Specifičnost segmenta energetske efikasnosti jeste postojanje sistema finansijske podrške koju pruža država u različitim formama. Kod projekata energetske efikasnosti, uobičajeno je da postoji široka lepeza finansijskih proizvoda koji imaju za cilj da podrže dalji razvoj ovog tržišta i najčešće imaju formu zvanične razvojne pomoći (donacija), grantova, tehničke pomoći, specifičnih fondova i proizvoda EU, specifičnih sistema podrške države, proizvoda banaka.

Kako bi se na što bolji način ilustrovale moguće forme ove vrste pomoći javnog sektora, $\mathrm{u}$ daljem tekstu biće analizirane mere podrške koje se sprovode u Republici Srbiji, kao i finansijski instrumenti i aranžmani koji su aktuelni na tržištu Evropske unije.

\section{Mere podrške u oblasti energetske efikasnosti u Republici Srbiji}

Zakonom o efikasnom korišćenju energije predviđeno je osnivanje Budžetskog fonda za unapređenje energetske efikasnosti Republike Srbije (u daljem tekstu: Budžetski fond) koji će predstavljati efikasan način za prikupljanje i plasiranje sredstava u svrhu finansiranja ili sufinansiranja projekata, programa i aktivnosti koje za cilj imaju efikasnije korišćenje energije, i to za:

1. primenu tehničkih mera u cilju efikasnog korišćenja energije u sektorima proizvodnje, prenosa, distribucije i potrošnje energije;

2. podsticanje razvoja sistema energetskog menadžmenta za subjekte koji nisu obveznici tog sistema;

3. promovisanje i sprovođenje energetskih pregleda objekata, proizvodnih procesa i usluga;

4. izgradnju sistema za kombinovanu proizvodnju toplotne i električne energije ako su ispunjeni zahtevi u pogledu energetske efikasnosti postrojenja, propisani u skladu sa zakonom kojim se uređuje oblast energetike, a investitor toplotnu i električnu energiju koristi isključivo za sopstvene potrebe;

5. podsticanje razvoja energetskih usluga na tržištu Republike Srbije;

6. podsticanje upotrebe obnovljivih izvora energije za proizvodnju električne i toplotne energije za sopstvene potrebe;

7. druge namene u skladu sa zakonom.

Budžetski fond je evidencioni račun $u$ okviru glavne knjige trezora, i to u okviru razdela ministarstva nadležnog za poslove energetike (Ministarstvo rudarstva i energetike, 2013). Korišćenje sredstava iz Budžetskog fonda je u skladu sa godišnjim programom finansiranja aktivnosti i mera unapređenja efikasnog korišćenja energije. Za realizaciju ovog programa i preuzetih obaveza na osnovu 
Figure 1. Graphical representation of cooperation and financing within the ESCO concept

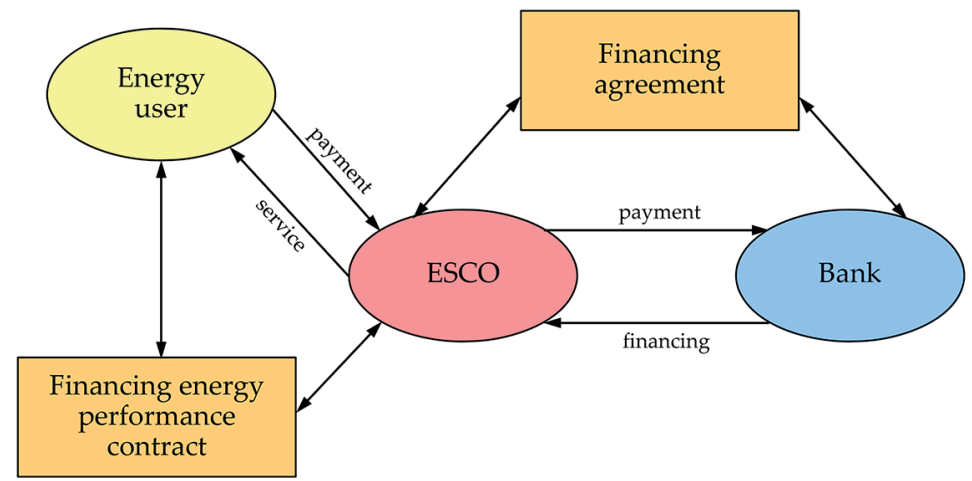

Source: Author

\section{Specific systems of support in energy efficiency financing}

Investing in energy efficiency projects faces a number of obstacles, such as very high initial costs, transaction costs, lack of capacity, low level of awareness or understanding of the concept of financing, or structural problems such as the so-called principal-agency problems (ICC, 2014).

The specificity of the energy

The main advantage of this model is that the private partner, who assumes the risk of achieving the projected and desired energy savings, guarantees a return on investment from the savings achieved and he is the party that provides the funding. The role of banks in public-private partnerships with the ESCO model is very large and significant: ESCO companies are partners of banks with the aim of providing partial or full financing of the project. On the domestic front, the further development of ESCOs and the market has very clear and bright prospects.

\section{Public Procurement Field}

Ministry of Mining and Energy adopted the Ordinance on the minimum criteria in terms of energy efficiency in the public procurement of goods (Ministry of Mining and Energy, 2015b), which prescribes the minimum criteria in terms of energy efficiency that purchasers (in terms of the law governing public procurement) determined in the procurement process of goods. Although these criteria do not directly affect a larger number of energy efficiency projects that the bank would finance, they certainly have an indirect effect and encourage the quality improvement of performance of public bodies by helping them become better informed and knowledgeable as bank clients who understand the importance and necessity of respecting the field of energy efficiency. efficiency segment is the existence of a system of financial support provided by the state in various forms. When it comes to energy efficiency projects, it is common that there is a wide range of financial products that aim to support the further development of this market usually taking the form of official development assistance, grants, technical assistance, specific EU funds and product-specific system of state support, bank products.

In order to better illustrate the possible forms of this kind of public sector assistance, hereinafter we will be analyzing the support measures implemented in the Republic of Serbia, as well as the financial instruments and arrangements that are incumbent on the EU market.

\section{Energy efficiency support measures in the Republic of Serbia}

The Law on Efficient Use of Energy prescribes the establishment of the Budget Fund for the improvement of energy efficiency of the Republic of Serbia (hereinafter: Budget Fund), which will represent an efficient way of raising and placing funds for the financing or co-financing of projects, programs and activities aimed at the more efficient use energy in case of the following:

1. the application of technical measures aimed at the efficient use of energy in the sectors of production, transmission, distribution and consumption of energy;

2. encouraging the development of energy management systems for entities that are not liable to that system; 
Uredbe o utvrđivanju Programa finansiranja aktivnosti i mera unapređenja efikasnog korišćenja energije u 2015. godini (Ministarstvo rudarstva i energetike, 2015a) koriste se sredstva Budžetskog fonda koja su obezbeđena na osnovu Zakona o budžetu Republike Srbije za 2016. godinu ("Službeni glasnik RS", broj 103/15) u iznosu od 160.000.000 dinara i sredstva donacija u ukupnom iznosu do 500.000 USD, koja će se, u skladu sa Sporazumom sa UNDP, koristiti narednih pet godina. Sredstva za finansiranje projekata unapređenja energetske efikasnosti mogu se opredeliti kao bespovratna sredstva.

Korisnici sredstava su jedinice lokalne samouprave. Finansiranje projekata je skladu sa propisom kojim se uređuju bliži uslovi za raspodelu i korišćenje sredstava Budžetskog fonda, način raspodele tih sredstava, kao i način praćenja namenskog korišćenja sredstava i ugovorenih prava i obaveza i Sporazumom sa UNDP. U javnom sektoru sredstva će se koristiti naročito za primenu sledećih mera energetske efikasnosti:

1. poboljšanje, odnosno zamena spoljnih prozora i vrata;

2. postavljanje ili poboljšanje postojeće termičke izolacije zidova, krova, tavanica iznad otvorenih prolaza, zidova i podova na tlu, kao i ostalih zidova prema negrejanom prostoru (termički omotač zgrade);

3. zamena ili ugradnja efikasnih sistema za klimatizaciju;

4. unapređenje, odnosno modernizacija sistema unutrašnjeg osvetljenja u objektima;

5. zamena sistema ili dela sistema grejanja efikasnijim sistemom (npr. zamena kotla efikasnijim, ugradnja pumpi sa promenljivim brojem obrtaja, ugradnja uređaja za automatsku regulaciju rada sistema grejanja, itd.);

6. opremanjegrejneinstalacije sa termostatskim ventilima i po potrebi uređajima za merenje predate količine toplote objektu, odnosno delu objekta;

7. instalacija kotlova na biomasu;

8. 8) instalacija solarnih kolektora za grejanje potrošne tople vode;

9. instalacija toplotnih pumpi manjeg kapaciteta sa visokim koeficijentom učinka (COP);
10. modernizacija sistema javnog osvetljenja u gradovima i opštinama;

11. ugradnja uređaja i primenu specifičnih IT alata za daljinsku kontrolu i automatsku regulaciju rada energetskih sistema $\mathrm{u}$ objektima;

12. druge mere za unapređenje energetske efikasnosti.

\section{Finansijske šeme podrške za projekte energetske efikasnosti u Evropskoj uniji}

Da bi se dostigli ciljevi postavljeni u oblasti energetske efikasnosti do 2020 godine u EU, procenjuje se da je neophodno investirati oko 100 milijardi EUR na godišnjem nivou (Evropska komisija, 2016). Javni fondovi, sredstva javnog sektora u EU su značajno povećani za oblast EE, ali je dalji cilj da se mobilišu i sredstva privatnog sektora i investicije u ovoj oblasti.

U EU postoji više izvora, načina i formi finansijske podrške za projekte EE. Neki od najznačajnijih su:

a. HORIZON 2020 - ova sredstva su usmerena na podršku istraživanju, razvoj novih tehnologija energetske efikasnosti. Sredstva se koriste za energetski efikasne zgrade, industriju, sistem hlađenja i zagrevanja, MSP i proizvode i usluge koji su u vezi sa energijom. Sredstva se takođe koriste za poboljšanje atraktivnosti investicija $u$ energetsku efikasnost.

b. odrška za razvoj projekta (Project Development Assistance) - ovaj program pomaže promoterima javnog i privatnog sektora u razvijanju održivih investicija energetske efikasnosti u rasponu od 6 do 50 miliona EUR. U okviru ove vrste finansijske podrške, postoji i program ELENA - kojim upravlja Evropska investiciona banka i koji je $\mathrm{u}$ formi donacije lokalnoj samoupravi $\mathrm{u}$ cilju razvoja i pokretanja održivih investicija energetske efikasnosti i to velikog obima. ELENA pokriva i $90 \%$ troškova tehničke podrške.

c. European Energy Efficiency Fund - ovaj fond $\mathrm{u}$ iznosu od 265 miliona EUR nalazi se $\mathrm{u}$ vidu instrumenata različite kombinacije kredita i kapitala koji je na raspolaganju kako javnom tako i privatnom sektoru.

d. Private Financing for Energy Efficiency instrument (PF4EE) - novi finansijski 
3. the promotion and implementation of energy audits of buildings, production processes and services;

4. the construction of a system for the combined production of heat and electricity if the requirements are met in terms of energy efficiency installations, laid down in accordance with the law governing the field of energy, and the investor uses the thermal and electrical energy exclusively for his own purposes;

5. encouraging the development of the energy services market of the Republic of Serbia;

6. promoting the use of renewable energy sources for the production of electricity and thermal energy for one's own purposes;

7. other purposes in accordance with the law.

The Budget Fund is a sort of a record account within the Treasury Book, under the competence of the ministry responsible for energy affairs (Ministry of Mining and Energy, 2013). Using funds from the Budget Fund is in accordance with the annual program of financing activities and measures to improve the efficient use of energy. For the realization of this program and the commitments on the basis of the Regulation on defining the Program for financing activities and measures to improve the efficient use of energy in 2015 (Ministry of Mining and Energy, 2015a) the Budget Fund sources are used and provided based on the Law on Budget of the Republic of Serbia for 2016 (Official Gazette of RS, No 103/15) in the amount of 160 million dinars and donations amounting to 500,000 USD, which will be used in the next five years in accordance with the Agreement with the UNDP. The funds for financing projects to improve energy efficiency can be dedicated as non-returnable grants.

The beneficiaries are the local selfgovernment units. The financing of projects is consistent with the regulation governing the detailed conditions for the allocation and use of funds of the Budget Fund, the manner of distribution of these funds, the method of monitoring the appropriate use of funds and contractual rights and obligations and the Agreement with UNDP. In the public sector the funds will be used in particular for the application of the following energy efficiency measures:

1. improvement or replacement of external doors and windows;

2. installation or improvement of existing thermal insulation of walls, roofs, ceilings above open passages, walls and floors on the ground, and other walls facing unheated areas (thermal building envelope)

3. replacement or installation of efficient air-conditioning systems;

4. improvement, and modernization of the interior lighting in buildings;

5. replacement of the system or part of the heating system with a more efficient system (e.g. replacement of boilers with more efficient ones, installation of pumps with variable speed, installation of automatic regulation of the heating system, etc.);

6. equipping the heating systems with thermostatic valves and, where appropriate, the devices for measuring the amount of heat emitted to the facility, or part of the building;

7. installation of biomass boilers;

8. installation of solar collectors for heating domestic hot water;

9. installation of low capacity heat pumps with those with high coefficient of performance (COP)

10. modernization of public lighting in towns and municipalities;

11. mounting devices and application-specific IT tools for remote control and automatic regulation of the energy system in facilities;

12. other measures to upgrade energy efficiency. 
instrument $\mathrm{u}$ okviru EU LIFE programa (finansijski instrument za klimatske promene) koji ko-finansira različite programe energetske efikasnosti u nekoliko zemalja EU.

e. European Structural \& Investment Funds (ESIF) - u okviru ovog fonda, više od 27 milijardi EUR je rezervisano za podršku uspostavljanju ekonomije sa niskom emisijom ugljenika (low-carbon economy).

f. Energy Efficiency Financial Institutions Group (EEFIG) - Fond EEFIG je osnovala Evropska komisija i Ekološko Finansijska inicijativa Ujedinjenih nacija (United Nations Environment Programme Finance Initiative (UNEP FI) ) 2013. godine sa ciljem utvrđivanja faktora tražnje i ponude za finansiranje, odnosno kako da se prevaziđu izazovi za obimnije investiranje u energetsku efikasnost.

\section{Primer dobre prakse - inovativni pristup Microsoft-a i Fiat-a energetskoj efikasnosti}

Usvajanje mera energetske efikasnosti može da dovede i do smanjenja emisije štetnih gasova i do 49\% (ICC, 2014, p. 2). Ovaj cilj je, između ostalog, bio vodilja u zajedničkoj saradnji između Microsoft-a i Fiat-a povodom inovativnog projekta koji je kao primer dobre prakse prikazan u tekstu dole.

Fiat je italijanski proizvođač automobila i motora, finansijska i industrijska grupa sa sedištem u Torinu, Italija. Automobili Fiat su konstruisani širom sveta, a 2009. godine Fiat je postao šesti najveći proizvođač automobila na svetu, kao i najveći italijanski proizvođač automobila. Danas kompanija sarađuje sa skoro 200.000 zaposlenih širom sveta i njegov globalni godišnji prihod je oko US \$ 87 milijardi (ICC, 2009, p. 17). Od 1995. godine, poslovna jedinica $u$ okviru Microsoft-a posvećena autoindustriji, uspostavila je zajedničku saradnju sa auto industrijom u cilju iznalaženja napredne tehnologije za dizajniranje naprednih Sistema informacija za unutrašnjost automobila, navigacije i sistema za zabavu. Kao rezultat te saradnje u 2007. godini, Fiat Group Automobiles i Microsoft Auto Poslovna jedinica je objavio novi sistem pod nazivom EcoDrive koji u direktnoj interakciji sa vozačima omogućava da smanje svoj uticaj na životnu sredinu.

EcoDrive je inovativna, jednostavna za korišćenje aplikacija koju je razvio Microsoft za Fiat automobile i koja obraćajući se direktno vozaču, analizira njegov stil vožnje i daje uputstva kako da troši manje goriva, smanji emisiju CO2 i uštedi novac. EcoDrive potrošnja je izgrađena na Blue \& Me, sistemu baziranom na Bluetooth tehnologiji koji su zajednički razvili Fiat i Microsoft za procenu stila vožnje vozača tokom normalnog dana vožnje. Način na koji vozač ubrzava, koči, i prebacuje brzine se automatski meri i analizira u odnosu na emisiju gasova automobila, potrošnju goriva i izduvnih gasova. Vozači takođe mogu da smanje potrošnju goriva i uštede novac, čime direktno ostvaruju energetsku efikasnost. Kod kuće, vozač može da ima uvid u rezultete svoje vožnje: tako što izvadi standardni USB fleš disk sa USB porta na tabli ili na pregradi u automobiliu, priključi ga u kompjuter i preuzme informacije o svom najnovijem iskustvu vožnje i njenim parametrima. Aplikacija za softver pokazuje vozaču koliko kilograma emisije je automobil proizveo u poslednjoj vožnji, i kako vozač može da smanji tu emisiju i dostigne energetsku efikasnost ukoliko primeni način vožnje koja je više ekološki prihvatljiva.

Aplikacijajesamounapređenjevećpostojećeg sistema rada $u$ automobilima. Današnja vozila stvaraju mnogo manje zagađenja i emituju daleko manje ugljen-dioksida u poređenju sa onima od pre deset godina. Veći deo

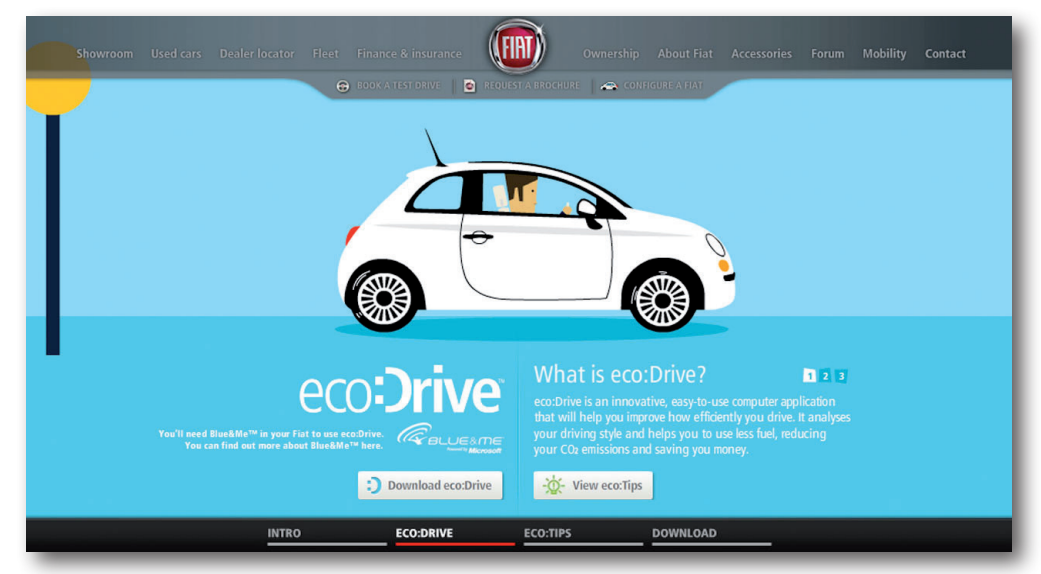




\section{Financial support schemes for energy efficiency in the European Union}

To achieve the objectives set in the area of energy efficiency by 2020 in the EU, it is estimated that it is necessary to invest around EUR 100 billion annually (European Commission, 2016). Public funds, public sector in the EU have increased substantially in the field of EE, but it is a further aim to mobilize the resources of the private sector and investment in this area. In the EU there are multiple sources, methods and forms of financial support for the EE projects. Some of the most important are:

a. HORIZON 2020 - these funds are aimed at supporting research, development of new technologies for energy efficiency. The funds are used for energy-efficient buildings, industry, cooling and heating, SMEs and the products and services that are energy-related. Funds are also used to enhance the attractiveness of investment in energy efficiency.

b. Support to the development of the project (Project Development Assistance) - This program helps promoters of the public and private sector in developing sustainable investments in energy efficiency in the range of 6 to 50 million EUR. Within these types of financial support, there is a program ELENA - managed by the European Investment Bank, which is in the form of donations to the local government for the development and launching of sustainable investments in energy efficiency on a large scale. ELENA covers $90 \%$ of the cost for technical support.

c. European Energy Efficiency Fund - this fund in the amount of EUR 265 million is in the form of instruments of various combinations of loans and equity that is available to the public and the private sector.

d. Private Financing for Energy Efficiency instrument (PF4EE) - a new financial instrument within the EU LIFE program (financial instrument for climate change), which co-financed a variety of energy efficiency programs in several EU countries.

e. European Structural \& Investment Funds (ESIF) - within this fund, more than 27 Billion EUR is reserved for launching the economy with low CO2 emission (lowcarbon economy).

f. Energy Efficiency Financial Institutions Group (EEFIG) - EEFIG Fund is launched by the European Commission and United Nations Environment Programme Finance Initiative (UNEP FI) in 2013 with the aim of fostering factors of financing demand and supply, as well as exploring the ways to overcome the challenges for more extensive investments in energy efficiency.

\section{Case study of good practice - Microsoft and Fiat innovative approach to Energy Efficiency}

The adoption of energy efficiency measures can lead to a reduction in greenhouse gas emissions by up to $49 \%$ (ICC, 2014, p.2). This objective, among other things, was the guiding principle in a joint cooperation between Microsoft and Fiat on the occasion of an innovative project that is shown in the text below as a good practice case study.

Fiat is the Italian car and engine maker, financial and industrial group based in Turin, Italy. Fiat cars are constructed all over the world, and in 2009, Fiat became the sixth largest automaker in the world, as well as Italy's largest

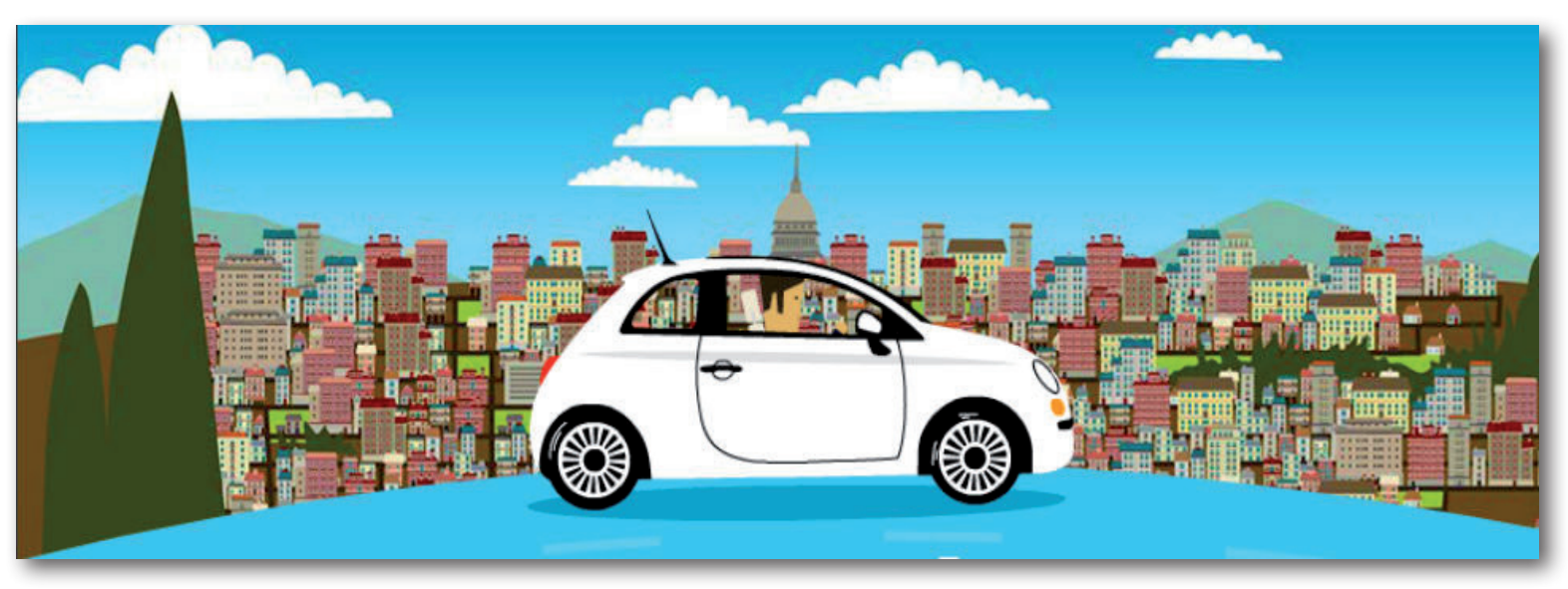


tog napretka je zbog računara ugrađenih u automobile koji prilagođavaju protok goriva ili dovod vazduha. Ali, dok ti kompjuteri razgovaraju samo sa drugim hardverskim komponentama $\mathrm{u}$ automobilu, aplikacija EcoDrive $\mathrm{u}$ automobilu može da komunicira sa vozačima i usmerava ih kako da smanje emisiju štetnih gasova i povećaju energetsku efikasnost. Tako je ideja iza EcoDrive, koji je baziran na Microsoft tehnologiji, postala prvi na svetu uređaj koji komunicira direktno sa vozačima i može da im pomogne da promene svoje vozačke navike na način koji može smanjiti auto emisije i povećati energetsku efikasnost. Sa EcoDrive, Fiat i Microsoft su razvili metod za praćenje vozačevog ponašanja na analizu puteva i ponudu saveta i nakon što je putovanje završeno.

Značaj ove aplikacije je u sledećem: značajne redukcije emisija štetnih gasova, smanjenje potrošnje goriva kroz bolje navike vozača, potignuta energetska efikasnost, inovativni pristup energetskoj efikasnosti. EcoDrive ilustruje potencijal softverske tehnologije za smanjenje emisije i energetsku efikasnost kod automobila širom sveta. U SAD, na primer, vozila učestvuju sa oko jedne četvrtine $u$ godišnjoj emisiji $\mathrm{CO} 2$, u vidu gasa koji je odgovoran za globalno zagrevanje. Smanjenje emisije za 20 ili čak $10 \%$ kroz bolje navike vozača bio bi ogroman doprinos naporima autoindustrije za proizvodnju više ekološki prihvatljivih automobila.

\section{Zaključak}

Uvođenje sistema energetskog
menadžmenta, sprovođenje Ugovora o
osnivanju Energetske zajednice i obaveza
koje proističu iz njega, obaveza izrade i
sprovođenja Akcionog plana za energetsku
efikasnost Republike Srbije isl, ukazuju na to
da je energetska efikasnost oblast koja ima
prvenstveno karakter javnog cilja. Ovako
postavljena, energetska efikasnost će kao javni
cilj i javna politika dobijati na svom značaju
i u budućnosti i biti u vrhu liste prioriteta

društveno ekonomskog razvoja. Kako se veliki broj indikatora i ciljeva postavljenih $\mathrm{u}$ nacionalnom okviru mogu realizovati putem projekata, energetska efikasnost predstavlja i veliku poslovnu mogućnost za banke koje posluju u Srbiji i druge potencijalne finansijere. Uloga banaka je u oblasti energetske efikasnosti višestruka: od konvencionalnog oblika kreditiranja sektora privrede i sektora stanovništva, preko multisektorske ekspertize do uloge nacionalnog partnera $u$ realizaciji postavljenih ciljeva i partnera $u$ finansiranju ESCO kompanija i projekata javno-privatnog partnerstva. Uloga banaka je dakle, važna i raznovrsna, i takva uloga će takođe jačati vremenom. Uloga banaka i njihovih finansijskih instrumenata kojima podržavaju razvoj oblasti energetske efikasnosti umnogome je olakšana i prisustvom mehanizama i rešenja regulative koja povoljno utiče na predvidivost projekta i stabilnost uslova poslovanja a time i nižu cenu finansiranja. Poseban deo tih mera jesu i finansijske šeme podrške za projekte energetske efikasnosti; u Republici Srbiji najznačajniji je Budžetski fond za unapređenje energetske efikasnosti Republike Srbije, dok je u zemljama EU takva pomoć raznovrsnija i pokriva različite aspekte i faze razvoja projekta energetske efikasnosti (od istraživanja, podrške razvoju projekta, do samog finansiranja). Imajući u vidu postojanje složenog zakonskog okvira u ovoj oblasti koji korespondira međunarodnim pravilima i propisima, finansijskih mera podrške, kao i postojanje drugih instrumenata i mehanizama koji afirmativno utiču na dalji i veći angažman banaka u ovoj oblasti, evidentna je važnost prisustva banaka kao dugoročnih partnera $\mathrm{i}$ to $\mathrm{u}$ veoma dugoj perspektivi. Konačno, prisustvo drugih zainteresovanih strana na tržištu, naročito $\mathrm{u}$ domenu informacionih tehnologija (npr. Microsoft) koje imaju za cilj realizaciju inovacija u domenu energetske efikasnosti, predstavlja dodatni faktor za neophodno prisustvo i angažovanost banaka sa kapacitetom inovativnog i specifičnog finansiranja u ovim poslovima. 
carmaker. Today, the company cooperates with almost 200,000 employees worldwide and its global annual revenue is about US \$ 87 billion (ICC, 2009, p.17). Since 1995, the business unit within Microsoft in charge of the automotive industry has established a joint cooperation with the auto industry in order to explore advanced technologies for the design of superior information systems for car interiors, navigation and entertainment system. As a result of this collaboration, in 2007, Fiat Group Automobiles and Microsoft Auto Business Unit have announced a new system called EcoDrive which interacts directly with the drivers to reduce their environmental impact. EcoDrive is an innovative, easy to use application developed by Microsoft for Fiat cars which speaks directly to the driver, analyzes his driving style and gives instructions on how to use less fuel, reduce $\mathrm{CO} 2$ emissions and save money. EcoDrive consumption is built on Blue\&Me system based on Bluetooth technology, jointly developed by Fiat and Microsoft for the evaluation of the driving style during normal driving days. The manner in which the driver accelerates, brakes and shifts speeds is automatically measured and analyzed in relation to the emissions of car gasses and fuel consumption.

The drivers can also reduce fuel consumption and save money, thus directly contributing to the energy efficiency. At home, the drivers can have access to the results of their journey: they may take a standard USB flash drive from the USB port on the board or on the automobile bulkhead, plug it into a computer and download information about his/her latest driving experience and its parameters. Application software shows to the driver how many kilograms of emissions the car produced in the last run, and how drivers can reduce the emissions and achieve energy efficiency when applying the driving mode that is more environmentally friendly. This application is just the improvement of the existing system in cars. Today's vehicles produce much less pollution and emit far less carbon dioxide compared with those of ten years ago. Much of this progress is due to the computers installed in cars that adapt to the flow of fuel or air supply. But while these computers communicate only with other hardware components in the car,
EcoDrive applications can communicate with the drivers and guide them on how to reduce emissions and increase energy efficiency. Thus, the idea behind EcoDrive, which is based on Microsoft technology, has evolved into the world's first device that interacts directly with drivers helping them to change their driving habits in ways that can reduce auto emissions and increase energy efficiency. With EcoDrive, Fiat and Microsoft have developed a method for monitoring drivers' behavior on the roads, while the analysis offers advice even after the trip ends.

The importance of this application is reflected in the following: substantial reduction of greenhouse gas emissions, reducing fuel consumption through better driving habits, achieved energy efficiency, innovative approach to energy efficiency. EcoDrive software illustrates the potential of technology to reduce emissions and energy efficiency of cars around the world. In the US, for example, vehicles account for about one quarter of the annual emissions of $\mathrm{CO} 2$ in the form of gas, which is responsible for global warming. Reducing emissions by $20 \%$ or even $10 \%$ through better driving habits would be a huge contribution to the automotive industry's efforts to produce more environmentally friendly cars.

\section{Conclusion}

The introduction of the energy management system, the implementation of the Treaty establishing the Energy Community and the obligations deriving from it, the duty of drafting and implementing the Action Plan for Energy Efficiency of the Republic of Serbia, etc., indicate that energy efficiency is an area that primarily has the character of a public purpose. Thus positioned, as a public goal and public policy, energy efficiency will be receiving higher importance in the future, being the top priority for socio-economic development. As the large number of indicators and targets set in the national framework can be implemented by projects, energy efficiency represents a great business opportunity for banks operating in Serbia as well as for other potential financiers. The role of banks in the field of energy efficiency is multiple: from conventional forms 


\section{Literatura / References}

1. Bratković, A. at al. 2016. Knjiga preporuka Nacionalnog konventa o Evropskoj uniji. 2015-2016. Beograd: Evropski pokret u Srbiji.

2. Ministarstvo rudarstva i energetike. 2013. Drugi akcioni plan za energetsku efikasnost Republike Srbije za period od 2013. do 2015. godine (Second action plan for energy efficiency of the Republic of Serbia for the period from 2013 to 2015). Beograd: Službeni glasnik RS, broj 98/2013.

3. Evropska komisija. Finansiranje energetske efikasnosti. https://ec.europa.eu/energy/en/ topics/energy-efficiency/financing-energyefficiency (pristup 3/7/2016).

4. International Chamber of Commerce - ICC Commission on Environment and Energy. 2014. Enabling Framework to scale up investments in energy efficiency. Paris: ICC.

5. International Chamber of Commerce - ICC Commission on Environment and Energy. 2009. Energy Efficiency with case studies. http://www.iccwbo.org/Advocacy-Codesand-Rules/Document-centre/2009/ICCdiscussion-paper-on-energy-efficiencywith-case-studies-\%282009\%29/ (pristup 6/9/2016).

6. Ministarstvo rudarstva i energetike. 2013. Odluka o otvaranju Budžetskog fonda za unapređenje energetske efikasnosti Republike Srbije (Decree on establishment of the Budget Fund for the improvement of energy efficiency of the Republic of Serbia). Beograd: Službeni glasnik RS, broj 92/13.

7. Ministarstvo rudarstva i energetike. 2015a. Uredba o utvrđivanju Programa finansiranja aktivnosti i mera unapređenja efikasnog korišćenja energije u 2015. godini (Regulation on the Implementation Program financing activities and measures to improve the efficient use of energy in 2015). Beograd: Službeni glasnik RS, broj 75/15.

8. Ministarstvo rudarstva i energetike. 2015b. Pravilnik o minimalnim kriterijumima $\mathrm{u}$ pogledu energetske efikasnosti u postupku javne nabavke dobara (Ordinance on the minimum criteria in terms of energy efficiency in the public procurement of goods). Beograd: Službeni glasnik RS, broj 111/15 od 29.12.2015. godine.
9. Ministarstvo rudarstva i energetike. 2015c Pravilnik o utvrđivanju modela ugovora o energetskim uslugama za primenu mera poboljšanja energetske efikasnosti kada su korisnici iz javnog sektora (Ordinance on establishing model contracts for energy services for the implementation of measures to improve energy efficiency when the users from the public sector). Beograd: Službeni glasnik RS, broj 41/2015.

10. Ministarstvo rudarstva i energetike. 2016. Uredba o utvrđivanju graničnih vrednosti godišnje potrošnje energije na osnovu kojih se određuje koja privredna društva su obveznici sistema energetskog menadžmenta, godišnjih ciljeva uštede energije i obrasca prijave o ostvarenoj potrošnji energije (Regulation on establishing limits power consumption on the basis of which determines which companies are liable to the energy management system, the annual objectives of energy savings and the application form on the realized energy consumption). Beograd: Službeni glasnik RS, broj 18/16.

11. Wiser, R. and Pickle, S. 1997. Financing Investments in Renewable Energy: The Role of Policy Design and Restructuring. Berkeley: University of California.

12. Sredojević, G. S. 2010. Javno-privatno partnerstvo. Beograd. Arhipelag i Institut Ekonomskih nauka.

13. Zakon o javno-privatnom partnerstvu i koncesijama (Law on PPP and Concessions) 2011/2016. Službeni glasnik RS, broj 88/11 i $15 / 2016$.

14. Zakon o efikasnom korišćenju energije (Law on Efficient Use of Energy) („Službeni glasnik RS", broj 25/13).

15. Zakon o energetici (Law on Energy) (,,Službeni glasnik RS ,,, broj 145/14). 
of lending to the corporate and household sector, through multi-sectoral expertise to the role of national partners in the realization of the set goals and funding partners of ESCO companies and public-private partnerships. The role of banks is therefore important and diverse, and this role will also strengthen over time. The role of banks and their financial instruments that support the development of energy efficiency is greatly facilitated by the presence of mechanisms and frameworks that favorably affect the stability and predictability of project and business conditions and therefore the lower cost of financing. A special part of these measures are financial support schemes for energy efficiency projects; in the Republic of Serbia, the most important is the Budgetary Fund for the improvement of energy efficiency of the Republic of Serbia, while in the EU countries such assistance varies and covers different aspects and stages of development of the energy efficiency projects (from research, support to project development, to financing). Given the existence of a complex legal framework in this area, which corresponds to international rules and regulations, financial support measures, as well as the existence of other instruments and mechanisms that facilitate the further and greater involvement of banks in this area, there is evidence of the importance of the presence of banks as longterm partners. Ultimately, other stakeholders in the market who have an innovative approach in the field of energy efficiency, particularly in the field of information technology (e.g. Microsoft), represent an additional factor in favor of the necessary presence and involvement of banks in these matters with the capacity for innovative and specific funding. 